\title{
Advances in Experimental Targeted Therapy and Immunotherapy for Patients with Glioblastoma Multiforme
}

\author{
JIRI POLIVKA JR. ${ }^{1,2}$, JIRI POLIVKA ${ }^{3}$, LUBOS HOLUBEC ${ }^{1}$, TEREZA KUBIKOVA ${ }^{1,2}$, \\ VLADIMIR PRIBAN ${ }^{4}$, ONDREJ HES ${ }^{5}$, KRISTYNA PIVOVARCIKOVA ${ }^{5}$ and INKA TRESKOVA ${ }^{6}$ \\ ${ }^{1}$ Biomedical Center, Faculty of Medicine in Plzen, Charles University, Plzen, Czech Republic; \\ ${ }^{2}$ Department of Histology and Embryology, Faculty of Medicine in Plzen, \\ Charles University, Plzen, Czech Republic; \\ ${ }^{3}$ Department of Neurology, Faculty of Medicine in Plzen, Charles University, \\ Faculty Hospital Plzen, Plzen, Czech Republic; \\ ${ }^{4}$ Department of Neurosurgery, Faculty of Medicine in Plzen, Charles University, \\ Czech Republic and Faculty Hospital Plzen, Plzen, Czech Republic; \\ ${ }^{5}$ Department of Pathology, Faculty of Medicine in Plzen, Charles University, \\ and Faculty Hospital Plzen, Plzen, Czech Republic; \\ ${ }^{6}$ Department of Surgery, Faculty of Medicine in Plzen, Charles University, \\ and Faculty Hospital Plzen, Plzen, Czech Republic
}

\begin{abstract}
Glioblastoma multiforme (GBM) represents the most malignant primary brain tumor in adults with generally dismal prognosis, early clinical deterioration and high mortality. GBM is extremely invasive, characterized by intense and aberrant vascularization and high resistance to multimodal treatment. Standard therapy (surgery, radiotherapy and chemotherapy with temozolomide) has very limited effectiveness, with median overall survival of patients no longer than 15 months. Progress in genetics and epigenetics of GBM over the past decade has revealed various aberrations in cellular signaling pathways, the tumor microenvironment, and pathological angiogenesis. A number of targeted anticancer drugs, such as small-molecule kinase inhibitors and monoclonal antibodies, have been evaluated in clinical trials with newly-diagnosed, as well as recurrent GBM. Unfortunately, to date, only a single antiangiogenic agent, bevacizumab, has been approved for the treatment of recurrent GBM in the USA and Canada. The novel
\end{abstract}

This article is freely accessible online.

Correspondence to: Jiri Polivka, Department of Neurology, Faculty Hospital Plzen, alej Svobody 80, 304 60, Plzen, Czech Republic. E-mail: polivka@fnplzen.cz

Key Words: Glioblastoma multiforme, GBM, targeted therapy, immunotherapy, immune checkpoint inhibitors, PD1 inhibition, CTLA4 inhibition, clinical trials, personalized medicine, review. possibilities of cancer immunotherapy, especially immune checkpoint inhibitors, are being evaluated in clinical trials of patients with GBM. The most recent clinical experiences with targeted therapy as well as immunotherapy of GBM are given in this review. The relative lack of success of some of these approaches recently revealed in well-designed randomized clinical trials is also discussed.

Glioblastoma multiforme (GBM) belongs to the largest group of primary central nervous system (CNS) tumors, so-called gliomas, which are formed from supporting glial cells in the brain parenchyma $(1,2)$. GBM represents the most common and most malignant tumor in this class, with an incidence of $3-4 / 100,000 /$ year $(3,4)$. GBM is an extremely invasive and difficult to treat tumor, characterized by intense and aberrant vascularization and high resistance to radiotherapy (RT) and chemotherapy (CHT). The current standard of care for patients with newly-diagnosed GBM comprises of neurosurgery and subsequent concomitant chemoradiotherapy by fractionated external-beam RT and systemic temozolomide followed by systemic temozolomide in the adjuvant setting (5). There are only very limited possibilities for the treatment of subsequent recurrences, generally with minimal clinical efficacy (6). Despite intensive multimodal treatment strategies, the median survival of patients with GBM is still 12.1-14.6 months and only $3-5 \%$ of patients survive longer than 3 years (7).

Enormous progress has been made in the genetics and epigenetics of GBM during the past decade. The Cancer 
Genome Atlas Research Network consortium carried out multiplatform analysis (DNA mutations, mRNA, microRNA expressions) of 500 tumor tissue samples from patients with untreated primary GBM (8). This initiative, together with the other large multiplatform studies, revealed several abnormalities in a diversity of mutated genes and cellular signaling pathways involved in high-grade glioma development and progression (812). The most important genetic and epigenetic aberrations were found in following cellular signaling pathways: i) Kirsten rat sarcoma viral oncogene homolog (KRAS) and phosphoinositide 3-kinase (PI3K) oncogenic pathways (88\% of GBM), ii) the p53 pathway (87\% of GBM), iii) cell-cycle regulatory pathway (78\% of GBM), and iv) the newly-discovered alterations in metabolic pathways including isocitrate dehydrogenases 1 and 2 (IDHI/2) mutations (10\% of GBM). The mutations in IDHI/2 serve also as an independent and important GBM prognostic factor (13-15). Their routine assessment is now highly recommended in the clinical management of patients with glioma (including GBM) according to the recently updated World Health Organization (WHO) 2016 classification of CNS tumors (16-18).

The GBM microenvironment and its involvement in cancer development and progression was also extensively studied, especially tumor angiogenesis and aberrations in anticancer immune responses $(19,20)$. Together these findings allow the possibility of developing innovative and better personalized treatment strategies for clinical patient management in the future. The most recent advances in targeted therapy as well as immunotherapy for GBM are given in this review. The relative lack of success of some of these approaches, as recently revealed from well-designed randomized clinical trials, is also discussed.

\section{Perspectives on Novel Therapies for GBM}

The standard therapeutic protocols for the treatment of GBM have only limited benefits and provide a median survival of patients of no longer than 15 months (7). The novel so-called targeted therapies can affect and inhibit various tumor-specific features, such as altered cellular signaling pathways, aberrant vascularization, or the tumor microenvironment and impaired anticancer immune response $(21,22)$. Genetic and epigenetic studies in GBM have revealed potential new targets in cancer cells and the surrounding tumor microenvironment that can be therapeutically influenced by the small molecules and monoclonal antibodies $(4,23)$. New approaches of GBM immunotherapy could lead to a fundamental breakthrough into the treatment of high-grade gliomas (20).

However, the vast molecular heterogeneity associated with aberrant GBM signaling pathways contributes to the relative lack of success of these therapeutic strategies. A recent study identified a distinct mutation profile of recurrent glioma that varied from the initial mutation analyses in the same patient
(24). The exomes of 23 initially low-grade gliomas and recurrent tumors resected from the same patients were sequenced and the mutation profiles were mutually compared. In $10(43 \%)$ of these cases, $50 \%$ or fewer of the mutations present in the initial tumor were found at recurrence. Moreover, the mutational profile of GBM is also affected by CHT as recurrent tumors exhibit temozolomide-induced damage to the DNA mismatch repair system resulting in a hypermutated phenotype (25). Another study revealed the possibility of transition proneural gene expression pattern in GBM to a mesenchymal pattern at recurrence that also negatively influenced the effectiveness of new drugs applied at the beginning of the treatment in newly-diagnosed disease (10).

These and other mechanisms, such as the lack of tumor dependence on the proposed target, failure of drug penetration into the CNS, or clonal evolution and antigen escape of tumor after effective therapeutic intervention, could be reasons for the relative lack of success of targeted approaches in the treatment of gliomas. Only a small clinical benefit has been demonstrated with these agents so far, which is discussed in more detail in the following text.

Overcoming these barriers will probably require the use of individualized molecular profiling of each GBM tumor at initial diagnosis and also at recurrence, and application of personalized medicine principles for combinations of targeted therapies with other types of treatment for highgrade gliomas, including GBM.

\section{Inhibitors of Growth Factors and Their Receptors, Inhibitors of Intracellular Signaling Pathways}

These are relatively new molecules are able to specifically inhibit various aberrantly activated cell signaling pathways which lead to the formation and progression of cancer $(4,22$, 26). Such effects can be achieved by inhibiting specific growth factors and their receptors, including the epidermal growth factor family (EGF) and their receptors (EGFR), plateletderived growth factors (PDGF) and their receptors (PDGFR), insulin-like growth factors (IGF), fibroblast growth factor (FGF) and their receptors and others that are overexpressed or mutated in a high proportion of GBMs $(9,27)$.

Molecular aberrations in EGFR signalling, comprising mutations and gene overexpression, are described in approximately $50 \%$ of GBMs (8). Therefore aberrantly activated EGFR could be a possible therapeutic target, similar to the situation common in other tumor types (28-30). One of the approved drugs directed against EGFR is the small-molecule kinase inhibitor gefitinib. In an early phase II clinical trial of recurrent GBM treated with gefitinib, the progression-free survival (PFS) at 6 months was $13 \%$ and the median overall survival (OS) was 10 months (31). There were more recent studies with gefitinib as monotherapy or in combinations for GBM treatment with results of only very 
limited efficacy compared to standard treatment (32-34). Another EGFR inhibitor also examined in the GBM setting is erlotinib. A number of phase II trials of erlotinib as a single agent showed minimal benefit for GBM treatment and modest survival benefit in combination with other agents (35-37). Another potentially promising EGFR inhibitor is lapatinib. This agent was tested in multiple clinical trials in patients with GBM but again with very limited antitumor effect (38-40). The newer irreversible EGFR inhibitor afatinib was recently evaluated as a monotherapy and in combination with temozolomide in phase I/II study of patients with recurrent GBM (41). Afatinib had a manageable safety profile but only limited activity. Cetuximab is a chimeric monoclonal antibody with activity against EGFR. Cetuximab was tested in the small group of patients with GBM but also with poor results (42). Some improvement was observed in a phase II study evaluating the combination of cetuximab, irinotecan, and bevacizumab. However, the efficacy data were not superior compared to results with bevacizumab and irinotecan alone (43). The observed effects of EGFR inhibitors in the treatment of patients with GBM are generally weak. Better results could possibly be achieved by stratification of patients eligible for treatment by presence of overexpression or specific mutations of EGFR in their tumor tissue (44-46).

PDGFR is another cell surface receptor frequently overexpressed and activated in GBM, especially in its proneural subtype $(8,47)$. The aberrant activation of PDGFR assists in the transition from lower-grade glioma to GBM and PDGF ligand stimulates tumor growth and angiogenesis (48, 49). Imatinib is a kinase inhibitor of PDGRF, mast/stem cell growth factor receptor (c-KIT), and oncogene fusion protein $\mathrm{BCR}-\mathrm{ABL}$ that was also extensively examined in patients with GBM. PFS of $16 \%$ at 6 months was observed in one phase II trial of patients with recurrent disease (50). Further multicenter phase II studies confirmed that imatinib as a monotherapy or in combination therapy failed to improve PFS or OS in patients with $\operatorname{GBM}(51,52)$. Multikinase inhibitors influencing tumor angiogenesis, namely sunitinib, sorafenib, and vandetanib, also have inhibitory effect on PDGFR. These substances were also evaluated in the treatment of GBM (53, 54). However, more recent multicentric randomized phase II clinical trial of RT and temozolomide with and without vandetanib in patients with newly diagnosed GBM showed no significant OS benefit of combination compared with the parallel control arm, which led to an early termination of the study (55). Newer multikinase inhibitors affecting PDGFR such as dasatinib or nintedanib also failed to improve OS in patients with recurrent GBM (56-58). Based on the results from these and other clinical trials with various targeted drugs inhibiting overexpressed PDGFR, this approach unfortunately does not seem to be an effective therapeutic strategy for patients with GBM at the moment.
Intracellular signaling pathway components mediate the response of cells to such growth factors and their interactions with cell surface receptors. Inhibition of such aberrant signaling components can be a promising targeted therapeutic strategy in $\operatorname{GBM}(4,22)$. Protein kinase C (PKC) is an important driver of the signal propagation from several growth factors, such as EGF and PDGF, stimulating glioma cell proliferation. Examples of drugs that inhibit PKC and were evaluated in patients with GBM are tamoxifen $(59,60)$ and enzastaurin $(61,62)$. Again, minimal or no benefit was observed. Mammalian target of rapamycin (mTOR) is a crucial intracellular protein kinase involved in cell growth signaling. It transduces the signals from PI3K as well as the KRAS pathways (22). Mutations in the tumor suppressor phosphatase and tensin homolog $(P T E N)$, which normally inhibits PI3K signaling, often increases mTOR activity in GBM $(27,63)$. Therefore selective mTOR inhibition was extensively examined in GBM settings. The small-molecule mTOR inhibitor sirolimus was not effective as a single agent and had limited efficacy in a phase II trial in combination with erlotinib $(37,64)$. Another mTOR inhibitor, everolimus, showed no clear clinical benefit in combination with gefitinib for recurrent GBM (33). A recent phase II study evaluating everolimus, temozolomide, and RT in patients with newly diagnosed glioblastoma showed no appreciable survival benefit of the combination compared to historical controls treated with conventional therapy (65). The newer selective PI3K inhibitor PX-866 had a low overall response rate, with median PFS at 6 months of only $17 \%$ in a phase II study of patients with recurrent GBM (66). However, $21 \%$ of participants had durable stable disease even if no association between stable disease and molecular biomarkers was seen. There are many other targeted therapeutics affecting various aberrantly activated intracellular signaling pathways of cancer cells that are being examined in the GBM setting, such as inhibitors of poly (ADP-ribose) polymerase (PARP), signal transducer and activator of transcription 3 (STAT3) and others (4, 23, 67-69).

However, despite enormous advances in the research of targeted oncological therapy during the past two decades, none of these therapeutics have had proven significant PFS or OS benefit in well-designed phase III clinical trial for patients with newly diagnosed or recurrent GBM as a monotherapy or in combination with standard treatment regimes, which remains truly disappointing.

\section{Inhibition of Angiogenesis in GBM}

Cancer research has increasingly highlighted the fundamental role of the tumor microenvironment together with pathological angiogenesis and tumor neovascularization for the development and progression of malignant diseases (21, 70). The processes of pathological angiogenesis and possible 
mechanisms for their therapeutic inhibition have been extensively studied in $\operatorname{GBM}(19,71,72)$. The major role in tumor angiogenesis is played by vascular growth factors, especially vascular endothelial growth factor (VEGF) and its variant VEGF-A, primarily through its interactions with the VEGFR1 and VEGFR2 receptors found on endothelial as well as cancer cells. Excessive microvascular proliferation and VEGF overexpression were identified in tumor tissues from patients with GBM. Higher intra-tumoral as well as plasma VEGF concentrations were associated with rapid disease progression and presence of early recurrence of GBM (72-77). Therefore, the evaluation of antiangiogenic and anti-VEGF agents in GBM is highly needed.

The most widely used inhibitor of angiogenesis in advanced cancer treatment at the moment is bevacizumab, a humanized IgG1 monoclonal antibody against VEGF-A. Bevacizumab was extensively examined in clinical trials for treatment of recurrent as well as newly-diagnosed GBM, as a single agent and in various combinations with CHT and other targeted therapeutics $(71,78-83)$. Bevacizumab gained accelerated approval by the US Food and Drug Administration (FDA) for the treatment of recurrent GBM in 2009 based on a high radiographic response rates and prolonged PFS (84). The multicenter phase II BELOB clinical trial undertaken in 14 hospitals in the Netherlands suggested the possible OS benefit for patients with recurrent GBM treated with the combination of bevacizumab plus lomustine versus bevacizumab or lomustine alone (85). However, recently published results from the well-designed phase III European Organization for Research and Treatment of Cancer (EORTC) 26101 clinical trial failed to confirm the OS benefit of bevacizumab plus lomustine by comparison with lomustine alone $[9.1$ vs. 8.6 months, hazard ratio $(\mathrm{HR})=0.95,95 \%$ confidence interval $(\mathrm{CI})=0.74-1.21 ; p=0.65]$ in patients with first progression of GBM (86). On the other hand, PFS was longer in the combination arm by comparison with lomustine alone arm (4.2 vs. 1.5 months, $\mathrm{HR}=0.49,95 \% \mathrm{CI}=0.39-0.61$; $p<0.0001)$. Combinations of bevacizumab with standard treatment for newly-diagnosed GBM were also examined with encouraging results in initial phase II studies (87-89). Based on the previous results, two large phase III clinical trials were designed, AVAglio (NCT00943826) and RTOG0825 (NCT00884741), evaluating bevacizumab-containing regimes for patients with newly-diagnosed GBM. Unfortunately, neither trial demonstrated a benefit in OS for the combination of bevacizumab with standard RT plus temozolomide treatment compared to standard regimen alone $(90,91)$. Both studies demonstrated PFS survival benefit of combination, but it reached the pre-specified statistical significance only in the AVAglio trial (10.6 vs. 6.2 months, $p<0.001)$. Moreover, the baseline health-related quality of life and performance status were maintained longer and glucocorticoid use was lower in the bevacizumab arm in the
AVAglio trial but with more grade 3 and 4 adverse events (66.8\% vs. $51.3 \%)$. The retrospective analysis of molecular biomarkers in the AVAglio trial showed that patients with both isocitrate dehydrogenase 1 (IDHI) wild-type tumors and proneural pattern of gene expression may have derived 4.3 months of OS benefit with the addition of bevacizumab to a standard regimen (92). Because of the post-hoc nature of this analysis, the predictive effect in relation to bevacizumab treatment must be interpreted with caution. A recent metaanalysis examined clinical trials that compared bevacizumab plus RT/temozolomide with RT/temozolomide alone in patients with newly diagnosed GBM (79). The meta-analysis included 1,738 patients from three well-designed clinical trials. The result failed to demonstrate OS benefit $(\mathrm{HR}=1.04$, 95\% CI $=0.84-1.29 ; p=0.71)$ but identified increased PFS (HR=0.74, 95\% CI=0.62-0.88; $p=0.0009)$ for combined treatment with bevacizumab. Moreover, there was no increase in the 6-month survival $(p=0.13)$ and the rate of serious adverse events was higher in the bevacizumab-treated compared to the placebo group. Based on the results from the AVAglio and RTOG-0825 trials, bevacizumab was not approved for the treatment of patients with newly diagnosed GBM and remains a treatment alternative only in the recurrent setting in the USA and in Canada.

There is a substantial number of studies evaluating other inhibitors of angiogenesis in the treatment of newlydiagnosed as well as recurrent GBM. The VEGFR tyrosine kinase inhibitor cediranib showed activity in an early phase II clinical trial as a monotherapy in patients with recurrent GBM (93). Despite the promising results, cediranib demonstrated no PFS benefit as a monotherapy $(\mathrm{HR}=1.05$, 95\% $\mathrm{CI}=0.74-1.50, p=0.9)$ or in combination with lomustine ( $\mathrm{HR}=0.76,95 \% \mathrm{CI}=0.53-1.08 ; p=0.16)$ versus lomustine alone in patients with recurrent GBM in a phase III clinical trial (94). Cilengitide is an inhibitor of $\alpha v \beta 3$ and $\alpha v \beta 5$ integrin receptors that also blocks pathological tumor angiogenesis. Cilengitide was evaluated with promising results in phase II study as a monotherapy in patients with recurrent GBM (95). However, the phase III clinical trial evaluating cilengitide combined with standard treatment compared to standard regime alone failed to show significant OS benefit of the combination in patients with newly diagnosed GBM with O-6-methylguanine DNA methyltransferase $(M G M T)$ methylation (26.3 vs. 26.3 months; $\mathrm{HR}=1.02$, 95\% CI=0.81-1.29, $p=0.86$ ) (96). Another angiogenesis inhibitor aflibercept, a recombinant produced fusion protein that scavenges both VEGF and PDGF, was studied in the recurrent setting, but demonstrated minimal evidence of single-agent activity in patients with GBM with PFS at 6 months of only $7.7 \%$ (97). Unfortunately, apart from bevacizumab, no other inhibitor of angiogenesis has been approved for the treatment of patients with newly-diagnosed or recurrent GBM. 


\section{Immunotherapy of GBM}

Immunotherapy represents a very promising area of multimodal treatment for many types of cancer (98-101). There has also been great progress in immunotherapy research in GBM over the past few years. There are many different approaches currently being evaluated in GBM clinical trials, including passive immunotherapy with antibodies, utilization of autologously stimulated lymphocytes and cytokines, oncolytic virotherapy, and active immunotherapy with vaccine strategies based on tumor cells, peptides, or dendritic cells (DCs) $(20,102,103)$.

More than $40 \%$ of GBMs carry the unique deletion mutant variant of EGFR called EGFRvIII that is characterized by a deletion of 267 amino acids in the receptor extracellular domain $(104,105)$. This mutation causes constitutive ligandindependent receptor activation and signal propagation leading to cancer cell proliferation. The enhanced proliferation of EGFRvIII-positive cancer cells together with the lack of EGFRvIII expression in normal non-cancerous cells makes it an ideal candidate for targeted therapy and the use of personalized medicine in GBM treatment. Rindopepimut is a peptide-based vaccine (containing 13 EGFRvIII-specific amino acid sequences) targeted against EGFRvIII surface antigens. The phase I/II multicenter study evaluating rindopepimut in patients with newly diagnosed GBM showed very promising results, with a median PFS of 15.2 months and an OS of 23.6 months (106). Subsequent phase II clinical trial (ACT III) examined rindopepimut in combination with standard RT and temozolomide in 65 patients with newly diagnosed GBM overexpressing EGFRvIII (107). The median OS was 21.8 months. Patients with unmethylated MGMT promoter had an OS of 20.9 months, whereas those with methylated MGMT had longer OS of 40 months. Based on the very promising results from these early clinical trials, the double-blinded randomized multicenter phase III ACT IV clinical trial (NCT01480479) of rindopepimut in patients with newly diagnosed GBM was designed and started enrollment of patients (108). Unfortunately, rindopepimut combined with temozolomide failed to improve OS by comparison with the standard treatment (20.1 vs. 20 months; HR=1.01, 95\% $\mathrm{CI}=0.79-1.30, p=0.93)$. The study was discontinued in March 2016 after the second interim analysis, which was a true disappointment. At the same time, this example shows the importance of verification of promising preliminary results from early drug development in well-designed randomized placebo controlled phase III clinical trials. Rindopepimut is still being evaluated in the phase II ReACT clinical trial in combination with bevacizumab in patients with recurrent EGFRvIII-positive GBM (NCT01498328).

There are other peptide vaccines targeting tumor antigens, such as the HLA-restricted Wilms tumor 1 (WT1) 9-mer peptide vaccine, that was examined in patients with recurrent
GBM in a phase II clinical trial (109). The median PFS was 20 weeks and the PFS at 6 months was $33.3 \%$. A more recent phase II clinical trial with an autologous heat-shock proteinpeptide vaccine HSPPC-96 (vitespen) showed promising results in patients with recurrent GBM, with a median OS of 42.6 weeks (110).

DC vaccines use autologous tumor lysates or common tumor antigens to induce an immune response against cancer. These strategies were evaluated in early-phase clinical trials in newly-diagnosed GBM (111-114). DC vaccine loaded with autologous tumor lysate was examined in a phase I clinical trial with 56 patients with relapsed GBM, resulting in a median PFS of 3 months and median OS of 9.6 months, with 2-year OS of $14.8 \%$ (115). The same group investigated the integration of DC vaccine into the standard treatment of patients with newly-diagnosed GBM and achieved an unexpected median OS of 24 months (116). Another large double-blinded randomized phase II trial of DC vaccine (DCVax-L) in patients with newly diagnosed GBM also showed encouraging results, with a median OS of 3 years, with 4-year survival reaching $33 \%$, and $27 \%$ of patients exceeding 6-year survival from initial surgery $(117,118)$. However, the clarification of these promising results with DC vaccine strategies are essential in well-designed randomized phase III clinical trials, such as the DCVax-L phase III study (NCT00045968) which is now ongoing and whose final results are eagerly awaited.

\section{The Role of Immune Checkpoint Inhibitors in Glioblastoma Immunotherapy}

There has been dramatic success in the treatment of various advanced solid tumor types such as melanoma, renal cancer, lung cancer, head and neck cancer with the novel class of immunomodulatory anticancer agents called immune checkpoint inhibitors (98-101, 119-121). These therapeutics are able to block inhibitory molecules and their receptors on effector immune cells, which leads to a robust T-cell response against the tumor. At the moment there are FDAapproved monoclonal antibodies directed against distinct inhibitory molecules such as ipilimumab targeting cytotoxic T-lymphocyte antigen 4 (CTLA-4), nivolumab and pembrolizumab targeting programmed cell death 1 (PD-1) and atezolizumab targeting programmed cell death ligand 1 (PD-L1), and many others are in development. The great success of immune checkpoint inhibitors in a therapy of a number of advanced solid tumor type1 leading to the evaluation of these compounds in CNS gliomas, including GBM $(122,123)$.

There is comprehensive pre-clinical research supporting a role for immune checkpoint inhibitors in the treatment of GBM. In a preclinical study with a murine glioma model, treatment with CTLA-4 blockade effectively reversed 
glioma-induced changes to the $\mathrm{CD} 4^{+} \mathrm{T}$-cell compartment and enhanced the antitumor immunity (124). Another study with a mouse model of GBM showed the synergistic effect of combined treatment of systemic CTLA-4 blockade together with intratumoral interleukin 12 (IL12) application leading to tumor eradication even at advanced disease stages (125). The effectiveness of combined CTLA-4 with PD-L1 and indoleamine-2,3-dioxygenase 1 blockade was studied in mouse model of GBM. It was shown that $100 \%$ of mice $(\mathrm{n}=5)$ survived on the triple combination therapy for a long time (126). A more recent study with a murine model of GBM showed that anti-CTLA-4 plus anti-PD-1 therapy was able to cure $75 \%$ of the animals (12 out of 16 ), even with advanced and late-stage tumors (127).

Support for the rationale of using immune checkpoint inhibitors in the GBM setting has also come from substantial clinical findings. Firstly, these drugs effectively overcome the blood-brain barrier and are active in the CNS. The CTLA-4 inhibitor ipilimumab showed activity in patients with brain metastases of melanoma without significant CNS toxicity $(128,129)$. The PD-1 inhibitor pembrolizumab was active in the treatment of brain metastases in patients with melanoma or non-small-cell lung cancer with an acceptable safety profile $(130,131)$. Furthermore, PD-L1 expression level in the tumor tissue was positively associated with the likelihood of clinical benefit with PD-1 inhibitor in nonsmall-cell lung cancer as well as other tumor types (132, 133). A recent study showed robust and diffuse expression of PD-L1 assessed by immunohistochemistry in newlydiagnosed as well as recurrent GBM (88\% vs. $72.2 \%$, respectively), which is a relatively high percentage compared to other cancer types such as melanoma (134). Higher expression of PD-L1 in tumor tissue correlated with worse outcome in another study with 94 patients with GBM (135). Because of the promising pre-clinical experiments, proven activity in the CNS and the presence of targets in GBM tumor tissue, clinical trials with specific immune checkpoint inhibitors are warranted in patients with GBM in newly diagnosed as well as recurrent settings.

Clinical trials evaluating immune checkpoint inhibitors, including ipilimumab, nivolumab, pembrolizumab and others, in patients with GBM are currently being conducted (Table I). The phase III CheckMate 143 study (NCT02017717) is evaluating nivolumab alone and nivolumab plus ipilimumab versus bevacizumab as an active comparator in patients with recurrent GBM. The latest results included the observation of high activity of the nivolumab arm, with 12-month OS of $40 \%$ (136). Nivolumab alone was also the best tolerated arm with no new safety signals. Another currently running phase II clinical trial (NCT02337491) is validating the combination of pembrolizumab and bevacizumab in patients with recurrent GBM. Very preliminary results from six patients treated with the combination showed a median OS of 6.8 months and two patients remained alive long-term (327 and 328 days) (137). Pembrolizumab is also being examined in combination with bevacizumab and hypofractionated stereotactic RT in a phase I/II study (NCT02313272) in patients with recurrent GBM. Preliminary results from six patients who were treated with the combination showed durable disease control in all three patients evaluable for response (138). The phase II CheckMate 548 (NCT02667587) study is examining the combination of standard RT plus temozolomide treatment with nivolumab or placebo in patients with newly-diagnosed GBM. Moreover, the phase III CheckMate 498 (NCT02617589) clinical trial is evaluating the head to head comparison of nivolumab to temozolomide both in combination with standard RT in patients with newly diagnosed GBM with unmethylated $M G M T$ promoter in tumor tissue. The preliminary results from both these studies are eagerly awaited. Pembrolizumab is also being examined in the newly diagnosed setting in combination with standard RT plus temozolomide regime in a phase I/II (NCT02530502) clinical trial. The results have not been published yet. Newer checkpoint inhibitors are also being evaluated for the treatment of GBM patients, such as the phase II study of PDL1 inhibitor durvalumab in newly diagnosed as well as recurrent settings (NCT02336165). On the other hand, there are also conflicting results. A recently published retrospective analysis of 22 patients with heavily pretreated refractory progressive primary brain tumors (including 10 with GBM) treated with pembrolizumab as a salvage agent in four major Israeli brain tumor centers showed only limited OS of no more than 3.2 months (139). The authors do not recommend further use of pembrolizumab for the recurrent primary brain tumors until convincing positive prospective clinical trial data is published.

Immune checkpoint inhibitors represent a significant breakthrough in the treatment of various advanced tumor types (such as melanoma, renal cancer, lung cancer, head and neck cancer, and urinary bladder cancer) in recent years that has dramatically changed the prognosis of patients with cancer (98101, 119-121). In some cases, therapy with these drugs means long-term disease control or hopefully even cure. Although the preliminary results for these drugs are promising and generally also encouraging in patients with GBM, it is necessary to wait for the mature results from multiple phase III clinical trials that are expected to finish in 2018 and beyond.

\section{Summary}

GBM remains a devastating disease for patients and their families, with very poor prognosis and early clinical deterioration, despite aggressive multimodal treatment with surgery, RT and CHT. On the other hand, there have been many novel discoveries in basic and translational research in recent years. The genetic and epigenetic basis of GBM 
Polivka Jr. et al: Targeted Therapy and Immunotherapy in Patients with GBM (Review)

Table I. The major ongoing clinical trials incorporating immune checkpoint inhibitors into glioblastoma multiforme (GBM) treatment.

\begin{tabular}{|c|c|c|c|c|c|}
\hline $\begin{array}{l}\text { Immune checkpoint } \\
\text { inhibitor }\end{array}$ & $\begin{array}{l}\text { Phase of } \\
\text { the trial }\end{array}$ & $\begin{array}{l}\text { GBM } \\
\text { setting }\end{array}$ & $\begin{array}{l}\text { Estimated completion } \\
\text { date }\end{array}$ & $\begin{array}{c}\text { Other } \\
\text { intervention }\end{array}$ & $\begin{array}{l}\text { Clinical trial } \\
\text { identifier }\end{array}$ \\
\hline Nivolumab & III (CheckMate 498) & $\begin{array}{c}\text { Newly diagnosed } \\
\text { (MGMT unmethylated) }\end{array}$ & October 2019 & $\begin{array}{l}\text { Temozolomide, } \\
\text { Radiotherapy }\end{array}$ & NCT02617589 \\
\hline Nivolumab & II (CheckMate 548) & $\begin{array}{l}\text { Newly diagnosed } \\
\text { (MGMT methylated) }\end{array}$ & November 2020 & $\begin{array}{l}\text { Temozolomide } \\
\text { Radiotherapy }\end{array}$ & NCT02667587 \\
\hline Nivolumab & III (CheckMate 143) & Recurrent & January 2018 & Ipilimumab, Bevacizumab & NCT02017717 \\
\hline Nivolumab & I & Recurrent & August 2019 & Dendritic cell vaccine & NCT02529072 \\
\hline Pembrolizumab & $\mathrm{I} / \mathrm{II}$ & Newly diagnosed & March 2018 & $\begin{array}{l}\text { Temozolomide } \\
\text { Radiotherapy }\end{array}$ & NCT02530502 \\
\hline Pembrolizumab & II & Recurrent & 2016 & Bevacizumab & NCT02337491 \\
\hline Pembrolizumab & $\mathrm{I} / \mathrm{II}$ & Recurrent & December 2017 & $\begin{array}{c}\text { Bevacizumab } \\
\text { Hypofractionated stereotactic } \\
\text { irradiation }\end{array}$ & NCT02313272 \\
\hline Durvalumab & II & $\begin{array}{l}\text { Newly diagnosed } \\
\text { and recurrent }\end{array}$ & July 2017 & $\begin{array}{l}\text { Bevacizumab } \\
\text { Radiotherapy }\end{array}$ & NCT02336165 \\
\hline Durvalumab & II & Recurrent & December 2018 & Tremelimumab & NCT02794883 \\
\hline $\begin{array}{l}\text { BMS-986016 } \\
\text { (anti-LAG3 MAb) }\end{array}$ & I & Recurrent & December 2019 & $\begin{array}{l}\text { Nivolumab } \\
\text { Urelumab }\end{array}$ & NCT02658981 \\
\hline
\end{tabular}

$M G M T, O-6-$ Methylguanine DNA methyltransferase; $L A G 3$, lymphocyte-activation gene 3; MAb, monoclonal antibody.

formation and progression has been explored well, together with the mutational changes occurring during the standardtreatment course. Possible molecular and genetic targets in tumor cells that can be affected and inhibit by novel therapeutics are known. A number of targeted anticancer drugs are being evaluated as single agents or in combinations for newly diagnosed as well as recurrent GBM. However, despite excessive research in this area, to date only a single antiangiogenic monoclonal antibody, bevacizumab, has been approved for the treatment of recurrent GBM in the USA and Canada.

There has been significant progress in the research of immunotherapy strategies for GBM. The very successful anticancer therapeutics, immune checkpoints inhibitors, are now also being extensively evaluated in clinical trials with GBM and the results are eagerly awaited. These and other immunotherapeutic strategies together with a better understanding of the role of targeted anticancer drugs in this context hopefully will shed new light onto the future treatment of this serious and almost exclusively fatal disease.

\section{Conflicts of Interest}

The Authors declare that they have no conflict of interests regarding the publication of this article.

\section{Acknowledgements}

This work was supported by MH CZ - DRO (Faculty Hospital Plzen - FNP1, 00669806) and by the National Sustainability Program I (NPU I) Nr. LO1503 provided by the Ministry of Education Youth and Sports of the Czech Republic.

\section{References}

1 Dolecek TA, Propp JM, Stroup NE and Kruchko C: CBTRUS statistical report: primary brain and central nervous system tumors diagnosed in the United States in 2005-2009. NeuroOncol 14(Suppl 5): v1-49, 2012.

2 Louis DN, Ohgaki H, Wiestler OD, Cavenee WK, Burger PC, Jouvet A, Scheithauer BW and Kleihues P: The 2007 WHO Classification of Tumours of the Central Nervous System. Acta Neuropathol 114: 97-109, 2007.

3 Ostrom QT, Gittleman H, Liao P, Rouse C, Chen Y, Dowling J, Wolinsky Y, Kruchko $\mathrm{C}$ and Barnholtz-Sloan J: CBTRUS statistical report: primary brain and central nervous system tumors diagnosed in the United States in 2007-2011. NeuroOncol 16(Suppl 4): iv1-63, 2014.

4 Polivka J Jr, Polivka J, Rohan V, Topolcan O and Ferda J: New molecularly targeted therapies for glioblastoma multiforme. Anticancer Res 32: 2935-2946, 2012.

5 Stupp R, Mason WP, van den Bent MJ, Weller M, Fisher B, Taphoorn MJB, Belanger K, Brandes AA, Marosi C, Bogdahn U, Curschmann J, Janzer RC, Ludwin SK, Gorlia T, Allgeier A, Lacombe D, Cairncross JG, Eisenhauer E, Mirimanoff RO, European Organisation for Research and Treatment of Cancer Brain Tumor and Radiotherapy Groups and National Cancer Institute of Canada Clinical Trials Group: Radiotherapy plus concomitant and adjuvant temozolomide for glioblastoma. $\mathrm{N}$ Engl J Med 352: 987-996, 2005.

6 Tosoni A, Franceschi E, Poggi R and Brandes AA: Relapsed glioblastoma: treatment strategies for initial and subsequent recurrences. Curr Treat Options Oncol 17: 49, 2016.

7 Krex D, Klink B, Hartmann C, von Deimling A, Pietsch T, Simon M, Sabel M, Steinbach JP, Heese O, Reifenberger G, Weller M, Schackert G and German Glioma Network: Longterm survival with glioblastoma multiforme. Brain J Neurol 130: 2596-2606, 2007. 
8 Cancer Genome Atlas Research Network: Comprehensive genomic characterization defines human glioblastoma genes and core pathways. Nature 455: 1061-1068, 2008.

9 Parsons DW, Jones S, Zhang X, Lin JC-H, Leary RJ, Angenendt P, Mankoo P, Carter H, Siu I-M, Gallia GL, Olivi A, McLendon R, Rasheed BA, Keir S, Nikolskaya T, Nikolsky Y, Busam DA, Tekleab H, Diaz LA Jr, Hartigan J, Smith DR, Strausberg RL, Marie SKN, Shinjo SMO, Yan H, Riggins GJ, Bigner DD, Karchin R, Papadopoulos N, Parmigiani G, Vogelstein B, Velculescu VE and Kinzler KW: An integrated genomic analysis of human glioblastoma multiforme. Science 321: 1807-1812, 2008.

10 Phillips HS, Kharbanda S, Chen R, Forrest WF, Soriano RH, Wu TD, Misra A, Nigro JM, Colman H, Soroceanu L, Williams PM, Modrusan Z, Feuerstein BG and Aldape K: Molecular subclasses of high-grade glioma predict prognosis, delineate a pattern of disease progression, and resemble stages in neurogenesis. Cancer Cell 9: 157-173, 2006.

11 Ceccarelli M, Barthel FP, Malta TM, Sabedot TS, Salama SR, Murray BA, Morozova O, Newton Y, Radenbaugh A, Pagnotta SM, Anjum S, Wang J, Manyam G, Zoppoli P, Ling S, Rao AA, Grifford M, Cherniack AD, Zhang H, Poisson L, Carlotti CG, Tirapelli DP da C, Rao A, Mikkelsen T, Lau CC, Yung WKA, Rabadan R, Huse J, Brat DJ, Lehman NL, Barnholtz-Sloan JS, Zheng S, Hess K, Rao G, Meyerson M, Beroukhim R, Cooper L, Akbani R, Wrensch M, Haussler D, Aldape KD, Laird PW, Gutmann DH, TCGA Research Network, Noushmehr H, Iavarone A and Verhaak RGW: Molecular profiling reveals biologically discrete subsets and pathways of progression in diffuse glioma. Cell 164: 550-563, 2016.

12 Polivka J, Polivka J, Repik T, Rohan V, Hes O and Topolcan $O$ : Co-deletion of $1 \mathrm{p} / 19 \mathrm{q}$ as prognostic and predictive biomarker for patients in West Bohemia with anaplastic oligodendroglioma. Anticancer Res 36: 471-476, 2016.

13 Xia L, Wu B, Fu Z, Feng F, Qiao E, Li Q, Sun C and Ge M: Prognostic role of $I D H$ mutations in gliomas: a meta-analysis of 55 observational studies. Oncotarget 6: 17354-17365, 2015.

14 Polivka J, Polivka J Jr, Rohan V, Pesta M, Repik T, Pitule P and Topolcan O: Isocitrate dehydrogenase-1 mutations as prognostic biomarker in glioblastoma multiforme patients in west bohemia. BioMed Res Int 2014: 735659, 2014.

15 Polivka J, Polivka J Jr, Rohan V and Topolcan O: Glioblastoma multiforme - a review of pathogenesis, biomarkers and therapeutic perspectives. Cesk Slov Neurol N 76/109: 575-583, 2013.

16 Louis DN, Perry A, Reifenberger G, von Deimling A, Figarella-Branger D, Cavenee WK, Ohgaki H, Wiestler OD, Kleihues P and Ellison DW: The 2016 World Health Organization Classification of Tumors of the Central Nervous System: a summary. Acta Neuropathol (Berl) 131: 803-820, 2016.

17 Polivka J, Polivka J, Rohan V and Topolcan O: New treatment paradigm for patients with anaplastic oligodendroglial tumors. Anticancer Res 34: 1587-1594, 2014.

18 Polivka J, Krakorova K, Peterka M and Topolcan O: Current status of biomarker research in neurology. EPMA J 7: 14, 2016.

19 Popescu AM, Purcaru SO, Alexandru O and Dricu A: New perspectives in glioblastoma antiangiogenic therapy. Contemp Oncol Pozn Pol 20: 109-118, 2016.
20 Kamran N, Calinescu A, Candolfi M, Chandran M, Mineharu Y, Asad AS, Koschmann C, Nunez FJ, Lowenstein PR and Castro MG: Recent advances and future of immunotherapy for glioblastoma. Expert Opin Biol Ther: 1-20, 2016.

21 Hanahan D and Weinberg RA: Hallmarks of cancer: the next generation. Cell 144: 646-674, 2011.

22 Polivka J and Janku F: Molecular targets for cancer therapy in the PI3K/AKT/mTOR pathway. Pharmacol Ther 142: 164-175, 2014.

23 Chen R, Cohen AL and Colman H: Targeted therapeutics in patients with high-grade gliomas: past, present, and future. Curr Treat Options Oncol 17: 42, 2016.

24 Johnson BE, Mazor T, Hong C, Barnes M, Aihara K, McLean CY, Fouse SD, Yamamoto S, Ueda H, Tatsuno K, Asthana S, Jalbert LE, Nelson SJ, Bollen AW, Gustafson WC, Charron E, Weiss WA, Smirnov IV, Song JS, Olshen AB, Cha S, Zhao Y, Moore RA, Mungall AJ, Jones SJM, Hirst M, Marra MA, Saito N, Aburatani H, Mukasa A, Berger MS, Chang SM, Taylor BS and Costello JF: Mutational analysis reveals the origin and therapy-driven evolution of recurrent glioma. Science 343: 189193, 2014.

25 Cahill DP, Levine KK, Betensky RA, Codd PJ, Romany CA, Reavie LB, Batchelor TT, Futreal PA, Stratton MR, Curry WT, Iafrate $\mathrm{AJ}$ and Louis DN: Loss of the mismatch repair protein MSH6 in human glioblastomas is associated with tumor progression during temozolomide treatment. Clin Cancer Res Off J Am Assoc Cancer Res 13: 2038-2045, 2007.

26 Polivka J, Pesta M and Janku F: Testing for oncogenic molecular aberrations in cell-free DNA-based liquid biopsies in the clinic: Are we there yet? Expert Rev Mol Diagn 15: 1631-1644, 2015.

27 Rao SK, Edwards J, Joshi AD, Siu I-M and Riggins GJ: A survey of glioblastoma genomic amplifications and deletions. J Neurooncol 96: 169-179, 2010.

$28 \mathrm{Ke}$ E-E and Wu Y-L: EGFR as a pharmacological target in $E G F R$-mutant non-small-cell lung cancer: Where do we stand now? Trends Pharmacol Sci 37: 887-903, 2016.

29 Sacco AG and Worden FP: Molecularly targeted therapy for the treatment of head and neck cancer: a review of the ERBB family inhibitors. OncoTargets Ther 9: 1927-1943, 2016.

30 Zaniboni A and Formica V: The Best. First. Anti-EGFR before anti-VEGF, in the first-line treatment of $R A S$ wild-type metastatic colorectal cancer: from bench to bedside. Cancer Chemother Pharmacol, 2016.

31 Rich JN, Reardon DA, Peery T, Dowell JM, Quinn JA, Penne KL, Wikstrand CJ, Van Duyn LB, Dancey JE, McLendon RE, Kao JC, Stenzel TT, Ahmed Rasheed BK, Tourt-Uhlig SE, Herndon JE, Vredenburgh JJ, Sampson JH, Friedman AH, Bigner DD and Friedman HS: Phase II trial of gefitinib in recurrent glioblastoma. J Clin Oncol Off J Am Soc Clin Oncol 22: 133-142, 2004.

32 Franceschi E, Cavallo G, Lonardi S, Magrini E, Tosoni A, Grosso D, Scopece L, Blatt V, Urbini B, Pession A, Tallini G, Crinò $\mathrm{L}$ and Brandes AA: Gefitinib in patients with progressive high-grade gliomas: a multicentre phase II study by Gruppo Italiano Cooperativo di Neuro-Oncologia (GICNO). Br J Cancer 96: 1047-1051, 2007.

33 Kreisl TN, Lassman AB, Mischel PS, Rosen N, Scher HI, Teruya-Feldstein J, Shaffer D, Lis E and Abrey LE: A pilot study of everolimus and gefitinib in the treatment of recurrent glioblastoma (GBM). J Neurooncol 92: 99-105, 2009. 
34 Brown N, McBain C, Nash S, Hopkins K, Sanghera P, Saran F, Phillips M, Dungey F, Clifton-Hadley L, Wanek K, Krell D, Jeffries S, Khan I, Smith P and Mulholland P: Multi-center randomized phase II study comparing cediranib plus gefitinib with cediranib plus placebo in subjects with recurrent/ progressive glioblastoma. PloS One 11: e0156369, 2016.

35 Peereboom DM, Ahluwalia MS, Ye X, Supko JG, Hilderbrand SL, Phuphanich S, Nabors LB, Rosenfeld MR, Mikkelsen T, Grossman SA and New Approaches to Brain Tumor Therapy Consortium: NABTT 0502: a phase II and pharmacokinetic study of erlotinib and sorafenib for patients with progressive or recurrent glioblastoma multiforme. Neuro-Oncol 15: 490-496, 2013.

36 van den Bent MJ, Brandes AA, Rampling R, Kouwenhoven MCM, Kros JM, Carpentier AF, Clement PM, Frenay M, Campone M, Baurain J-F, Armand J-P, Taphoorn MJB, Tosoni A, Kletzl H, Klughammer B, Lacombe D and Gorlia T: Randomized phase II trial of erlotinib versus temozolomide or carmustine in recurrent glioblastoma: EORTC Brain Tumor Group study 26034. J Clin Oncol Off J Am Soc Clin Oncol 27: 1268-1274, 2009.

37 Reardon DA, Desjardins A, Vredenburgh JJ, Gururangan S, Friedman AH, Herndon JE, Marcello J, Norfleet JA, McLendon RE, Sampson JH and Friedman HS: Phase 2 trial of erlotinib plus sirolimus in adults with recurrent glioblastoma. J Neurooncol 96: 219-230, 2010.

38 Thiessen B, Stewart C, Tsao M, Kamel-Reid S, Schaiquevich P, Mason W, Easaw J, Belanger K, Forsyth P, McIntosh L and Eisenhauer E: A phase I/II trial of GW572016 (lapatinib) in recurrent glioblastoma multiforme: clinical outcomes, pharmacokinetics and molecular correlation. Cancer Chemother Pharmacol 65: 353-361, 2010.

39 Karavasilis V, Kotoula V, Pentheroudakis G, Televantou D, Lambaki S, Chrisafi S, Bobos M and Fountzilas G: A phase I study of temozolomide and lapatinib combination in patients with recurrent high-grade gliomas. J Neurol 260: 1469-1480, 2013.

40 Reardon DA, Groves MD, Wen PY, Nabors L, Mikkelsen T, Rosenfeld S, Raizer J, Barriuso J, McLendon RE, Suttle AB, Ma B, Curtis CM, Dar MM and de Bono J: A phase I/II trial of pazopanib in combination with lapatinib in adult patients with relapsed malignant glioma. Clin Cancer Res Off J Am Assoc Cancer Res 19: 900-908, 2013.

41 Reardon DA, Nabors LB, Mason WP, Perry JR, Shapiro W, Kavan P, Mathieu D, Phuphanich S, Cseh A, Fu Y, Cong J, Wind S, Eisenstat DD and BI 120036 Trial Group and the Canadian Brain Tumour Consortium: Phase I/randomized phase II study of afatinib, an irreversible ERBB family blocker, with or without protracted temozolomide in adults with recurrent glioblastoma. Neuro-Oncol 17: 430-439, 2015.

42 Belda-Iniesta C, Carpeño J de C, Saenz EC, Gutiérrez M, Perona R and Barón MG: Long-term responses with cetuximab therapy in glioblastoma multiforme. Cancer Biol Ther 5: 912914, 2006.

43 Hasselbalch B, Lassen U, Hansen S, Holmberg M, Sørensen M, Kosteljanetz M, Broholm H, Stockhausen M-T and Poulsen HS: Cetuximab, bevacizumab, and irinotecan for patients with primary glioblastoma and progression after radiation therapy and temozolomide: a phase II trial. Neuro-Oncol 12: 508-516, 2010.
44 Mellinghoff IK, Wang MY, Vivanco I, Haas-Kogan DA, Zhu S, Dia EQ, Lu KV, Yoshimoto K, Huang JHY, Chute DJ, Riggs BL, Horvath S, Liau LM, Cavenee WK, Rao PN, Beroukhim R, Peck TC, Lee JC, Sellers WR, Stokoe D, Prados M, Cloughesy TF, Sawyers CL and Mischel PS: Molecular determinants of the response of glioblastomas to EGFR kinase inhibitors. N Engl J Med 353: 2012-2024, 2005.

45 Wachsberger PR, Lawrence RY, Liu Y, Rice B, Daskalakis C and Dicker AP: Epidermal growth factor receptor mutation status and RAD51 determine the response of glioblastoma to multimodality therapy with cetuximab, temozolomide, and radiation. Front Oncol 3: 13, 2013.

46 Gajadhar AS, Bogdanovic E, Muñoz DM and Guha A: In situ analysis of mutant EGFRs prevalent in glioblastoma multiforme reveals aberrant dimerization, activation, and differential response to anti-EGFR targeted therapy. Mol Cancer Res MCR 10: 428-440, 2012.

47 Verhaak RGW, Hoadley KA, Purdom E, Wang V, Qi Y, Wilkerson MD, Miller CR, Ding L, Golub T, Mesirov JP, Alexe G, Lawrence M, O'Kelly M, Tamayo P, Weir BA, Gabriel S, Winckler W, Gupta S, Jakkula L, Feiler HS, Hodgson JG, James CD, Sarkaria JN, Brennan C, Kahn A, Spellman PT, Wilson RK, Speed TP, Gray JW, Meyerson M, Getz G, Perou CM, Hayes DN and Cancer Genome Atlas Research Network: Integrated genomic analysis identifies clinically relevant subtypes of glioblastoma characterized by abnormalities in PDGFRA, IDH1, EGFR, and NF1. Cancer Cell 17: 98-110, 2010.

48 Hermanson M, Funa K, Koopmann J, Maintz D, Waha A, Westermark B, Heldin CH, Wiestler OD, Louis DN, von Deimling A and Nistér M: Association of loss of heterozygosity on chromosome $17 p$ with high platelet-derived growth factor alpha receptor expression in human malignant gliomas. Cancer Res 56: 164-171, 1996.

49 Ostman A: PDGF receptors - mediators of autocrine tumor growth and regulators of tumor vasculature and stroma. Cytokine Growth Factor Rev 15: 275-286, 2004.

50 Raymond E, Brandes AA, Dittrich C, Fumoleau P, Coudert B, Clement PMJ, Frenay M, Rampling R, Stupp R, Kros JM, Heinrich MC, Gorlia T, Lacombe D, van den Bent MJ and European Organisation for Research and Treatment of Cancer Brain Tumor Group Study: Phase II study of imatinib in patients with recurrent gliomas of various histologies: a European Organisation for Research and Treatment of Cancer Brain Tumor Group Study. J Clin Oncol Off J Am Soc Clin Oncol 26: 4659-4665, 2008.

51 Reardon DA, Dresemann G, Taillibert S, Campone M, van den Bent M, Clement P, Blomquist E, Gordower L, Schultz H, Raizer J, Hau P, Easaw J, Gil M, Tonn J, Gijtenbeek A, Schlegel U, Bergstrom P, Green S, Weir A and Nikolova Z: Multicentre phase II studies evaluating imatinib plus hydroxyurea in patients with progressive glioblastoma. Br J Cancer 101: 1995-2004, 2009.

52 Dresemann G, Weller M, Rosenthal MA, Wedding U, Wagner W, Engel E, Heinrich B, Mayer-Steinacker R, Karup-Hansen A, Fluge O, Nowak A, Mehdorn M, Schleyer E, Krex D, Olver IN, Steinbach JP, Hosius C, Sieder C, Sorenson G, Parker R and Nikolova Z: Imatinib in combination with hydroxyurea versus hydroxyurea alone as oral therapy in patients with progressive pretreated glioblastoma resistant to standard dose temozolomide. J Neurooncol 96: 393-402, 2010. 
53 Hainsworth JD, Ervin T, Friedman E, Priego V, Murphy PB Clark BL and Lamar RE: Concurrent radiotherapy and temozolomide followed by temozolomide and sorafenib in the first-line treatment of patients with glioblastoma multiforme. Cancer 116: 3663-3669, 2010.

54 Drappatz J, Norden AD, Wong ET, Doherty LM, Lafrankie DC, Ciampa A, Kesari S, Sceppa C, Gerard M, Phan P, Schiff D, Batchelor TT, Ligon KL, Young G, Muzikansky A, Weiss SE and Wen PY: Phase I study of vandetanib with radiotherapy and temozolomide for newly diagnosed glioblastoma. Int J Radiat Oncol Biol Phys 78: 85-90, 2010.

55 Lee EQ, Kaley TJ, Duda DG, Schiff D, Lassman AB, Wong ET, Mikkelsen T, Purow BW, Muzikansky A, Ancukiewicz M, Huse JT, Ramkissoon S, Drappatz J, Norden AD, Beroukhim R, Weiss SE, Alexander BM, McCluskey CS, Gerard M, Smith $\mathrm{KH}$, Jain RK, Batchelor TT, Ligon KL and Wen PY: A Multicenter, phase II, randomized, noncomparative clinical trial of radiation and temozolomide with or without vandetanib in newly diagnosed glioblastoma patients. Clin Cancer Res Off J Am Assoc Cancer Res 21: 3610-3618, 2015.

56 Muhic A, Poulsen HS, Sorensen M, Grunnet K and Lassen U: Phase II open-label study of nintedanib in patients with recurrent glioblastoma multiforme. J Neurooncol 111: 205-212, 2013.

57 Norden AD, Schiff D, Ahluwalia MS, Lesser GJ, Nayak L, Lee EQ, Rinne ML, Muzikansky A, Dietrich J, Purow B, Doherty LM, LaFrankie DC, Pulverenti JR, Rifenburg JA, Ruland SF, Smith KH, Gaffey SC, McCluskey C, Ligon KL, Reardon DA and Wen PY: Phase II trial of triple tyrosine kinase receptor inhibitor nintedanib in recurrent high-grade gliomas. J Neurooncol 121: 297-302, 2015.

58 Lassman AB, Pugh SL, Gilbert MR, Aldape KD, Geinoz S, Beumer JH, Christner SM, Komaki R, DeAngelis LM, Gaur R, Youssef E, Wagner H, Won M and Mehta MP: Phase 2 trial of dasatinib in target-selected patients with recurrent glioblastoma (RTOG 0627). Neuro-Oncol 17: 992-998, 2015.

59 Brandes AA, Ermani M, Turazzi S, Scelzi E, Berti F, Amistà P, Rotilio A, Licata C and Fiorentino MV: Procarbazine and highdose tamoxifen as a second-line regimen in recurrent highgrade gliomas: a phase II study. J Clin Oncol Off J Am Soc Clin Oncol 17: 645-650, 1999.

60 Spence AM, Peterson RA, Scharnhorst JD, Silbergeld DL and Rostomily RC: Phase II study of concurrent continuous temozolomide (TMZ) and tamoxifen (TMX) for recurrent malignant astrocytic gliomas. J Neurooncol 70: 91-95, 2004.

61 Wick W, Puduvalli VK, Chamberlain MC, van den Bent MJ, Carpentier AF, Cher LM, Mason W, Weller M, Hong S, Musib L, Liepa AM, Thornton DE and Fine HA: Phase III study of enzastaurin compared with lomustine in the treatment of recurrent intracranial glioblastoma. J Clin Oncol Off J Am Soc Clin Oncol 28: 1168-1174, 2010.

62 Kreisl TN, Kotliarova S, Butman JA, Albert PS, Kim L, Musib L, Thornton D and Fine HA: A phase I/II trial of enzastaurin in patients with recurrent high-grade gliomas. Neuro-Oncol 12: 181-189, 2010

63 Sathornsumetee S, Reardon DA, Desjardins A, Quinn JA, Vredenburgh JJ and Rich JN: Molecularly targeted therapy for malignant glioma. Cancer 110: 13-24, 2007.

64 Akhavan D, Cloughesy TF and Mischel PS: mTOR signaling in glioblastoma: lessons learned from bench to bedside. NeuroOncol 12: 882-889, 2010.
65 Ma DJ, Galanis E, Anderson SK, Schiff D, Kaufmann TJ, Peller PJ, Giannini C, Brown PD, Uhm JH, McGraw S, Jaeckle KA, Flynn PJ, Ligon KL, Buckner JC and Sarkaria JN: A phase II trial of everolimus, temozolomide, and radiotherapy in patients with newly diagnosed glioblastoma: NCCTG N057K. NeuroOncol 17: 1261-1269, 2015.

66 Pitz MW, Eisenhauer EA, MacNeil MV, Thiessen B, Easaw JC, Macdonald DR, Eisenstat DD, Kakumanu AS, Salim M, Chalchal H, Squire J, Tsao MS, Kamel-Reid S, Banerji S, Tu D, Powers J, Hausman DF and Mason WP: Phase II study of PX-866 in recurrent glioblastoma. Neuro-Oncol 17: 1270-1274, 2015.

67 Bai R-Y, Staedtke V and Riggins GJ: Molecular targeting of glioblastoma: Drug discovery and therapies. Trends Mol Med 17: 301-312, 2011.

68 Majuelos-Melguizo J, Rodríguez MI, López-Jiménez L, Rodríguez-Vargas JM, Martí Martín-Consuegra JM, Serrano-Sáenz S, Gavard J, de Almodóvar JMR and Oliver FJ: PARP targeting counteracts gliomagenesis through induction of mitotic catastrophe and aggravation of deficiency in homologous recombination in PTEN-mutant glioma. Oncotarget 6: 4790-4803, 2015.

69 Gray GK, McFarland BC, Nozell SE and Benveniste EN: NF-kB and STAT3 in glioblastoma: therapeutic targets coming of age. Expert Rev Neurother 14: 1293-1306, 2014.

70 Hui L and Chen Y: Tumor microenvironment: Sanctuary of the devil. Cancer Lett 368: 7-13, 2015.

71 Khasraw M, Ameratunga MS, Grant R, Wheeler H and Pavlakis $\mathrm{N}$ : Antiangiogenic therapy for high-grade glioma. Cochrane Database Syst Rev: CD008218, 2014.

72 Norden AD, Drappatz J and Wen PY: Novel anti-angiogenic therapies for malignant gliomas. Lancet Neurol 7: 1152-1160, 2008.

73 Salmaggi A, Eoli M, Frigerio S, Silvani A, Gelati M, Corsini E, Broggi $\mathrm{G}$ and Boiardi A: Intracavitary VEGF, bFGF, IL-8, IL-12 levels in primary and recurrent malignant glioma. J Neurooncol 62: 297-303, 2003.

74 Nam D-H, Park K, Suh YL and Kim J-H: Expression of VEGF and brain specific angiogenesis inhibitor-1 in glioblastoma: prognostic significance. Oncol Rep 11: 863-869, 2004.

75 Beal K, Abrey LE and Gutin PH: Antiangiogenic agents in the treatment of recurrent or newly diagnosed glioblastoma: analysis of single-agent and combined modality approaches. Radiat Oncol Lond Engl 6: 2, 2011.

76 Sica G, Lama G, Anile C, Geloso MC, La Torre G, De Bonis P, Maira G, Lauriola L, Jhanwar-Uniyal M and Mangiola A: Assessment of angiogenesis by CD105 and nestin expression in peritumor tissue of glioblastoma. Int J Oncol 38: 41-49, 2011.

77 Afshar Moghaddam N, Mahsuni P and Taheri D: Evaluation of Endoglin as an Angiogenesis Marker in Glioblastoma. Iran J Pathol 10: 89-96, 2015.

78 Curry RC, Dahiya S, Alva Venur V, Raizer JJ and Ahluwalia MS: Bevacizumab in high-grade gliomas: past, present, and future. Expert Rev Anticancer Ther 15: 387-397, 2015.

79 Fu P, He Y-S, Huang Q, Ding T, Cen Y-C, Zhao H-Y and Wei $\mathrm{X}$ : Bevacizumab treatment for newly diagnosed glioblastoma: Systematic review and meta-analysis of clinical trials. Mol Clin Oncol 4: 833-838, 2016.

80 Ghiaseddin A and Peters KB: Use of bevacizumab in recurrent glioblastoma. CNS Oncol 4: 157-169, 2015.

81 Vredenburgh JJ, Desjardins A, Herndon JE, Marcello J, Reardon DA, Quinn JA, Rich JN, Sathornsumetee S, Gururangan S, 
Sampson J, Wagner M, Bailey L, Bigner DD, Friedman AH and Friedman HS: Bevacizumab plus irinotecan in recurrent glioblastoma multiforme. J Clin Oncol Off J Am Soc Clin Oncol 25: 4722-4729, 2007.

82 Poulsen HS, Grunnet K, Sorensen M, Olsen P, Hasselbalch B, Nelausen K, Kosteljanetz M and Lassen U: Bevacizumab plus irinotecan in the treatment patients with progressive recurrent malignant brain tumours. Acta Oncol Stockh Swed 48: 52-58, 2009.

83 Verhoeff JJC, Lavini C, van Linde ME, Stalpers LJA, Majoie CBLM, Reijneveld JC, van Furth WR and Richel DJ: Bevacizumab and dose-intense temozolomide in recurrent highgrade glioma. Ann Oncol Off J Eur Soc Med Oncol ESMO 21: 1723-1727, 2010.

84 Friedman HS, Prados MD, Wen PY, Mikkelsen T, Schiff D, Abrey LE, Yung WKA, Paleologos N, Nicholas MK, Jensen R, Vredenburgh $\mathrm{J}$, Huang $\mathrm{J}$, Zheng $\mathrm{M}$ and Cloughesy $\mathrm{T}$ : Bevacizumab alone and in combination with irinotecan in recurrent glioblastoma. J Clin Oncol Off J Am Soc Clin Oncol 27: 4733-4740, 2009.

85 Taal W, Oosterkamp HM, Walenkamp AME, Dubbink HJ, Beerepoot LV, Hanse MCJ, Buter J, Honkoop AH, Boerman D, de Vos FYF, Dinjens WNM, Enting RH, Taphoorn MJB, van den Berkmortel FWPJ, Jansen RLH, Brandsma D, Bromberg JEC, van Heuvel I, Vernhout RM, van der Holt B and van den Bent MJ: Single-agent bevacizumab or lomustine versus a combination of bevacizumab plus lomustine in patients with recurrent glioblastoma (BELOB trial): a randomised controlled phase 2 trial. Lancet Oncol 15: 943-953, 2014.

86 Wick W, Brandes AA, Gorlia T, Bendszus M, Sahm F, Taal W, Taphoorn MJB, Domont J, Idbaih A, Campone M, Clement PM, Stupp R, Fabbro M, Rhun EL, Dubois F, Klein M, Platten M, Weller M, Golfinopoulos V and Bent MJVD: EORTC 26101 phase III trial exploring the combination of bevacizumab and lomustine in patients with first progression of a glioblastoma. J Clin Oncol 34, 2016.

87 Vredenburgh JJ, Desjardins A, Reardon DA, Peters KB, Herndon JE, Marcello J, Kirkpatrick JP, Sampson JH, Bailey L, Threatt S, Friedman AH, Bigner DD and Friedman HS: The addition of bevacizumab to standard radiation therapy and temozolomide followed by bevacizumab, temozolomide, and irinotecan for newly diagnosed glioblastoma. Clin Cancer Res Off J Am Assoc Cancer Res 17: 4119-4124, 2011.

88 Hainsworth JD, Shih KC, Shepard GC, Tillinghast GW, Brinker BT and Spigel DR: Phase II study of concurrent radiation therapy, temozolomide, and bevacizumab followed by bevacizumab/everolimus as first-line treatment for patients with glioblastoma. Clin Adv Hematol Oncol HO 10: 240-246, 2012.

89 Lai A, Tran A, Nghiemphu PL, Pope WB, Solis OE, Selch M, Filka E, Yong WH, Mischel PS, Liau LM, Phuphanich S, Black K, Peak S, Green RM, Spier CE, Kolevska T, Polikoff J, Fehrenbacher L, Elashoff R and Cloughesy T: Phase II study of bevacizumab plus temozolomide during and after radiation therapy for patients with newly diagnosed glioblastoma multiforme. J Clin Oncol Off J Am Soc Clin Oncol 29: 142$148,2011$.

90 Gilbert MR, Dignam JJ, Armstrong TS, Wefel JS, Blumenthal DT, Vogelbaum MA, Colman H, Chakravarti A, Pugh S, Won M, Jeraj R, Brown PD, Jaeckle KA, Schiff D, Stieber VW, Brachman DG, Werner-Wasik M, Tremont-Lukats IW, Sulman
EP, Aldape KD, Curran WJ and Mehta MP: A randomized trial of bevacizumab for newly diagnosed glioblastoma. N Engl J Med 370: 699-708, 2014

91 Chinot OL, Wick W, Mason W, Henriksson R, Saran F, Nishikawa R, Carpentier AF, Hoang-Xuan K, Kavan P, Cernea D, Brandes AA, Hilton M, Abrey L and Cloughesy T: Bevacizumab plus radiotherapy-temozolomide for newly diagnosed glioblastoma. N Engl J Med 370: 709-722, 2014.

92 Sandmann T, Bourgon R, Garcia J, Li C, Cloughesy T, Chinot OL, Wick W, Nishikawa R, Mason W, Henriksson R, Saran F, Lai A, Moore N, Kharbanda S, Peale F, Hegde P, Abrey LE, Phillips HS and Bais C: Patients with proneural glioblastoma may derive overall survival benefit from the addition of bevacizumab to first-line radiotherapy and temozolomide: retrospective analysis of the AVAglio trial. J Clin Oncol Off $\mathbf{J}$ Am Soc Clin Oncol 33: 2735-2744, 2015.

93 Batchelor TT, Duda DG, di Tomaso E, Ancukiewicz M, Plotkin SR, Gerstner E, Eichler AF, Drappatz J, Hochberg FH, Benner T, Louis DN, Cohen KS, Chea H, Exarhopoulos A, Loeffler JS, Moses MA, Ivy P, Sorensen AG, Wen PY and Jain RK: Phase II study of cediranib, an oral pan-vascular endothelial growth factor receptor tyrosine kinase inhibitor, in patients with recurrent glioblastoma. J Clin Oncol Off J Am Soc Clin Oncol 28: 2817-2823, 2010

94 Batchelor TT, Mulholland P, Neyns B, Nabors LB, Campone M, Wick A, Mason W, Mikkelsen T, Phuphanich S, Ashby LS, Degroot J, Gattamaneni R, Cher L, Rosenthal M, Payer F, Jürgensmeier JM, Jain RK, Sorensen AG, Xu J, Liu Q and van den Bent M: Phase III randomized trial comparing the efficacy of cediranib as monotherapy, and in combination with lomustine, versus lomustine alone in patients with recurrent glioblastoma. J Clin Oncol Off J Am Soc Clin Oncol 31: 3212-3218, 2013.

95 Reardon DA, Fink KL, Mikkelsen T, Cloughesy TF, O’Neill A, Plotkin S, Glantz M, Ravin P, Raizer JJ, Rich KM, Schiff D, Shapiro WR, Burdette-Radoux S, Dropcho EJ, Wittemer SM, Nippgen J, Picard M and Nabors LB: Randomized phase II study of cilengitide, an integrin-targeting arginine-glycineaspartic acid peptide, in recurrent glioblastoma multiforme. $\mathrm{J}$ Clin Oncol Off J Am Soc Clin Oncol 26: 5610-5617, 2008.

96 Stupp R, Hegi ME, Gorlia T, Erridge SC, Perry J, Hong Y-K, Aldape KD, Lhermitte B, Pietsch T, Grujicic D, Steinbach JP, Wick W, Tarnawski R, Nam D-H, Hau P, Weyerbrock A, Taphoorn MJB, Shen C-C, Rao N, Thurzo L, Herrlinger U, Gupta T, Kortmann R-D, Adamska K, McBain C, Brandes AA, Tonn JC, Schnell O, Wiegel T, Kim C-Y, Nabors LB, Reardon DA, van den Bent MJ, Hicking C, Markivskyy A, Picard M, Weller M, European Organisation for Research and Treatment of Cancer (EORTC), Canadian Brain Tumor Consortium and CENTRIC study team: Cilengitide combined with standard treatment for patients with newly diagnosed glioblastoma with methylated MGMT promoter (CENTRIC EORTC 26071-22072 study): a multicentre, randomised, open-label, phase 3 trial. Lancet Oncol 15: 1100-1108, 2014.

97 de Groot JF, Lamborn KR, Chang SM, Gilbert MR, Cloughesy TF, Aldape K, Yao J, Jackson EF, Lieberman F, Robins HI, Mehta MP, Lassman AB, Deangelis LM, Yung WKA, Chen A, Prados MD and Wen PY: Phase II study of aflibercept in recurrent malignant glioma: a North American Brain Tumor Consortium study. J Clin Oncol Off J Am Soc Clin Oncol 29: 2689-2695, 2011. 
98 Curtis SA, Cohen JV and Kluger HM: Evolving immuno-therapy approaches for renal cell carcinoma. Curr Oncol Rep 18: 57, 2016.

99 Khanna P, Blais N, Gaudreau P-O and Corrales-Rodriguez L: Immunotherapy comes of age in lung cancer. Clin Lung Cancer, 2016.

100 Donin NM, Lenis AT, Holden S, Drakaki A, Pantuck A, Belldegrun A and Chamie K: Immunotherapy in the treatment of urothelial carcinoma. J Urol, 2016.

101 Margolin K: The promise of molecularly targeted and immunotherapy for advanced melanoma. Curr Treat Options Oncol 17: 48, 2016.

102 Fecci PE, Heimberger AB and Sampson JH: Immunotherapy for primary brain tumors: no longer a matter of privilege. Clin Cancer Res Off J Am Assoc Cancer Res 20: 5620-5629, 2014.

103 Weathers S-P and Gilbert MR: Current challenges in designing GBM trials for immunotherapy. J Neurooncol 123: 331-337, 2015.

104 Pelloski CE, Ballman KV, Furth AF, Zhang L, Lin E, Sulman EP, Bhat K, McDonald JM, Yung WKA, Colman H, Woo SY, Heimberger AB, Suki D, Prados MD, Chang SM, Barker FG, Buckner JC, James CD and Aldape K: Epidermal growth factor receptor variant III status defines clinically distinct subtypes of glioblastoma. J Clin Oncol Off J Am Soc Clin Oncol 25: 22882294, 2007.

105 Gan HK, Kaye AH and Luwor RB: The EGFRvIII variant in glioblastoma multiforme. J Clin Neurosci Off J Neurosurg Soc Australas 16: 748-754, 2009.

106 Sampson JH, Aldape KD, Archer GE, Coan A, Desjardins A, Friedman AH, Friedman HS, Gilbert MR, Herndon JE, McLendon RE, Mitchell DA, Reardon DA, Sawaya R, Schmittling R, Shi W, Vredenburgh JJ, Bigner DD and Heimberger AB: Greater chemotherapy-induced lymphopenia enhances tumor-specific immune responses that eliminate EGFRvIII-expressing tumor cells in patients with glioblastoma. Neuro-Oncol 13: 324-333, 2011.

107 Schuster J, Lai RK, Recht LD, Reardon DA, Paleologos NA, Groves MD, Mrugala MM, Jensen R, Baehring JM, Sloan A, Archer GE, Bigner DD, Cruickshank S, Green JA, Keler T, Davis TA, Heimberger AB and Sampson JH: A phase II, multicenter trial of rindopepimut (CDX-110) in newly diagnosed glioblastoma: the ACT III study. Neuro-Oncol 17: 854-861, 2015.

108 Zussman BM and Engh JA: Outcomes of the ACT III study: Rindopepimut (CDX-110) therapy for glioblastoma. Neurosurgery 76: N17, 2015.

109 Izumoto S, Tsuboi A, Oka Y, Suzuki T, Hashiba T, Kagawa N, Hashimoto N, Maruno M, Elisseeva OA, Shirakata T, Kawakami M, Oji Y, Nishida S, Ohno S, Kawase I, Hatazawa J, Nakatsuka S-I, Aozasa K, Morita S, Sakamoto J, Sugiyama $\mathrm{H}$ and Yoshimine T: Phase II clinical trial of Wilms tumor 1 peptide vaccination for patients with recurrent glioblastoma multiforme. J Neurosurg 108: 963-971, 2008.

110 Bloch O, Crane CA, Fuks Y, Kaur R, Aghi MK, Berger MS, Butowski NA, Chang SM, Clarke JL, McDermott MW, Prados MD, Sloan AE, Bruce JN and Parsa AT: Heat-shock protein peptide complex-96 vaccination for recurrent glioblastoma: a phase II, single-arm trial. Neuro-Oncol 16: 274-279, 2014

111 Prins RM, Soto H, Konkankit V, Odesa SK, Eskin A, Yong WH, Nelson SF and Liau LM: Gene expression profile correlates with $\mathrm{T}$-cell infiltration and relative survival in glioblastoma patients vaccinated with dendritic cell immunotherapy. Clin Cancer Res Off J Am Assoc Cancer Res 17: 1603-1615, 2011.

112 Phuphanich S, Wheeler CJ, Rudnick JD, Mazer M, Wang H, Nuño MA, Richardson JE, Fan X, Ji J, Chu RM, Bender JG, Hawkins ES, Patil CG, Black KL and Yu JS: Phase I trial of a multi-epitope-pulsed dendritic cell vaccine for patients with newly diagnosed glioblastoma. Cancer Immunol Immunother CII 62: 125-135, 2013.

113 Yang L, Guo G, Niu X and Liu J: Dendritic Cell-Based Immunotherapy Treatment for Glioblastoma Multiforme. BioMed Res Int 2015: 717530, 2015.

114 Fong B, Jin R, Wang X, Safaee M, Lisiero DN, Yang I, Li G, Liau LM and Prins RM: Monitoring of regulatory $\mathrm{T}$ cell frequencies and expression of CTLA-4 on T-cells, before and after DC vaccination, can predict survival in GBM patients. PloS One 7: e32614, 2012.

115 De Vleeschouwer S, Fieuws S, Rutkowski S, Van Calenbergh F, Van Loon J, Goffin J, Sciot R, Wilms G, Demaerel P, Warmuth-Metz M, Soerensen N, Wolff JEA, Wagner S, Kaempgen E and Van Gool SW: Postoperative adjuvant dendritic cell-based immunotherapy in patients with relapsed glioblastoma multiforme. Clin Cancer Res Off $\mathrm{J}$ Am Assoc Cancer Res 14: 3098-3104, 2008.

116 Ardon H, Van Gool S, Lopes IS, Maes W, Sciot R, Wilms G, Demaerel P, Bijttebier P, Claes L, Goffin J, Van Calenbergh F and De Vleeschouwer S: Integration of autologous dendritic cell-based immunotherapy in the primary treatment for patients with newly diagnosed glioblastoma multiforme: a pilot study. J Neurooncol 99: 261-272, 2010.

117 Hdeib A and Sloan AE: Dendritic cell immunotherapy for solid tumors: evaluation of the DCVax ${ }^{\circledR}$ platform in the treatment of glioblastoma multiforme. CNS Oncol 4: 63-69, 2015.

118 Polyzoidis S and Ashkan K: DCVax ${ }^{\circledR}$-L--developed by Northwest Biotherapeutics. Hum Vaccines Immunother 10: 3139-3145, 2014.

119 Schoppy DW and Sunwoo JB: Immunotherapy for head and neck squamous cell carcinoma. Hematol Oncol Clin North Am 29: 1033-1043, 2015.

120 Modena A, Ciccarese C, Iacovelli R, Brunelli M, Montironi R, Fiorentino $\mathrm{M}$, Tortora $\mathrm{G}$ and Massari $\mathrm{F}$ : Immune checkpoint inhibitors and prostate cancer: A new frontier? Oncol Rev 10: 293, 2016

121 Mittica G, Genta S, Aglietta M and Valabrega G: Immune checkpoint inhibitors: A new opportunity in the treatment of ovarian cancer? Int J Mol Sci 17, 2016.

122 Preusser M, Lim M, Hafler DA, Reardon DA and Sampson JH: Prospects of immune checkpoint modulators in the treatment of glioblastoma. Nat Rev Neurol 11: 504-514, 2015.

123 Carter T, Shaw H, Cohn-Brown D, Chester K and Mulholland $\mathrm{P}$ : Ipilimumab and bevacizumab in glioblastoma. Clin Oncol R Coll Radiol G B, 2016.

124 Fecci PE, Ochiai H, Mitchell DA, Grossi PM, Sweeney AE, Archer GE, Cummings T, Allison JP, Bigner DD and Sampson JH: Systemic CTLA-4 blockade ameliorates glioma-induced changes to the $\mathrm{CD}^{+}{ }^{+} \mathrm{T}$-cell compartment without affecting regulatory T-cell function. Clin Cancer Res Off $\mathbf{J}$ Am Assoc Cancer Res 13: 2158-2167, 2007.

125 Vom Berg J, Vrohlings M, Haller S, Haimovici A, Kulig P, Sledzinska A, Weller $M$ and Becher B: Intratumoral IL-12 combined with CTLA-4 blockade elicits T-cell-mediated glioma rejection. J Exp Med 210: 2803-2811, 2013. 
126 Wainwright DA, Chang AL, Dey M, Balyasnikova IV, Kim CK, Tobias A, Cheng Y, Kim JW, Qiao J, Zhang L, Han Y and Lesniak MS: Durable therapeutic efficacy utilizing combinatorial blockade against IDO, CTLA-4, and PD-L1 in mice with brain tumors. Clin Cancer Res Off $\mathrm{J}$ Am Assoc Cancer Res 20: 5290-5301, 2014.

127 Reardon DA, Gokhale PC, Klein SR, Ligon KL, Rodig SJ, Ramkissoon SH, Jones KL, Conway AS, Liao X, Zhou J, Wen PY, Van Den Abbeele AD, Hodi FS, Qin L, Kohl NE, Sharpe AH, Dranoff $G$ and Freeman GJ: Glioblastoma eradication following immune checkpoint blockade in an orthotopic, immunocompetent model. Cancer Immunol Res 4: 124-135, 2016.

128 Margolin K, Ernstoff MS, Hamid O, Lawrence D, McDermott D, Puzanov I, Wolchok JD, Clark JI, Sznol M, Logan TF, Richards J, Michener T, Balogh A, Heller KN and Hodi FS: Ipilimumab in patients with melanoma and brain metastases: an open-label, phase 2 trial. Lancet Oncol 13: 459-465, 2012.

129 Di Giacomo AM, Ascierto PA, Queirolo P, Pilla L, Ridolfi R, Santinami M, Testori A, Simeone E, Guidoboni M, Maurichi A, Orgiano L, Spadola G, Del Vecchio M, Danielli R, Calabrò L, Annesi D, Giannarelli D, Maccalli C, Fonsatti E, Parmiani G and Maio M: Three-year follow-up of advanced melanoma patients who received ipilimumab plus fotemustine in the Italian Network for Tumor Biotherapy (NIBIT)-M1 phase II study. Ann Oncol Off J Eur Soc Med Oncol ESMO 26: 798803, 2015.

130 Goldberg SB, Gettinger SN, Mahajan A, Chiang AC, Herbst RS, Sznol M, Tsiouris AJ, Cohen J, Vortmeyer A, Jilaveanu L, Yu J, Hegde U, Speaker S, Madura M, Ralabate A, Rivera A, Rowen E, Gerrish H, Yao X, Chiang V and Kluger HM: Pembrolizumab for patients with melanoma or non-small-cell lung cancer and untreated brain metastases: early analysis of a non-randomised, open-label, phase 2 trial. Lancet Oncol 17: 976-983, 2016.

131 Rosell R and Karachaliou N: Trends in immunotherapy for brain metastases. Lancet Oncol 17: 859-860, 2016.

132 Garon EB, Rizvi NA, Hui R, Leighl N, Balmanoukian AS, Eder JP, Patnaik A, Aggarwal C, Gubens M, Horn L, Carcereny E, Ahn M-J, Felip E, Lee J-S, Hellmann MD, Hamid O, Goldman JW, Soria J-C, Dolled-Filhart M, Rutledge RZ, Zhang J, Lunceford JK, Rangwala R, Lubiniecki GM, Roach C, Emancipator K, Gandhi L and KEYNOTE-001 Investigators: Pembrolizumab for the treatment of non-small-cell lung cancer. N Engl J Med 372: 2018-2028, 2015.
133 Herbst RS, Soria J-C, Kowanetz M, Fine GD, Hamid O, Gordon MS, Sosman JA, McDermott DF, Powderly JD, Gettinger SN, Kohrt HEK, Horn L, Lawrence DP, Rost S, Leabman M, Xiao Y, Mokatrin A, Koeppen H, Hegde PS, Mellman I, Chen DS and Hodi FS: Predictive correlates of response to the anti-PD-L1 antibody MPDL3280A in cancer patients. Nature 515: 563-567, 2014.

134 Berghoff AS, Kiesel B, Widhalm G, Rajky O, Ricken G, Wöhrer A, Dieckmann K, Filipits M, Brandstetter A, Weller M, Kurscheid S, Hegi ME, Zielinski CC, Marosi C, Hainfellner JA, Preusser $M$ and Wick W: Programmed death ligand 1 expression and tumor-infiltrating lymphocytes in glioblastoma. Neuro-Oncol 17: 1064-1075, 2015.

135 Nduom EK, Wei J, Yaghi NK, Huang N, Kong L-Y, Gabrusiewicz K, Ling X, Zhou S, Ivan C, Chen JQ, Burks JK, Fuller GN, Calin GA, Conrad CA, Creasy C, Ritthipichai K, Radvanyi L and Heimberger AB: PD-L1 expression and prognostic impact in glioblastoma. Neuro-Oncol 18: 195-205, 2016.

136 Reardon DA, Sampson JH, Sahebjam S, Lim M, Baehring JM, Vlahovic G, Cloughesy TF, Strauss LC, Latek RR, Paliwal P, Harbison CT, Voloschin AD and Omuro AMP: Safety and activity of nivolumab (nivo) monotherapy and nivo in combination with ipilimumab (ipi) in recurrent glioblastoma (GBM): Updated results from checkmate-143. J Clin Oncol 34, 2016.

137 Reardon DA, Groot JFD, Colman H, Jordan JT, Daras M, Clarke JL, Nghiemphu PL, Gaffey SC and Peters KB: Safety of pembrolizumab in combination with bevacizumab in recurrent glioblastoma (rGBM). J Clin Oncol 34, 2016.

138 Sahebjam S, Johnstone PA, Forsyth PAJ, Arrington J, Vrionis FD, Etame AB, Tran ND, Dalvi PH, Kim S, Macaulay RJ, Chinnaiyan $\mathrm{P}$ and $\mathrm{Yu}$ M: Safety and antitumor activity of hypofractionated stereotactic irradiation (HFSRT) with pembrolizumab (Pembro) and bevacizumab (Bev) in patients (pts) with recurrent high grade gliomas: Preliminary results from phase I study. J Clin Oncol 34, 2016.

139 Blumenthal DT, Yalon M, Vainer GW, Lossos A, Yust S, Tzach L, Cagnano E, Limon D and Bokstein F: Pembrolizumab: first experience with recurrent primary central nervous system (CNS) tumors. J Neurooncol 129: 453-460, 2016.

Received November 15, 2016

Revised December 3, 2016

Accepted December 6, 2016 